\title{
Optimalisasi Daur Ulang Sampah Organik dan Anorganik untuk Meningkatkan Jiwa Enterpreneur Mahasiswa Teknik Sipil
}

\author{
Oleh : \\ Anita Intan Nura Diana ${ }^{1)}$, Subaidillah Fansuri²) \\ 1) ${ }^{2}$ Fakultas Teknik, Prodi Teknik Sipil, Universitas Wiraraja \\ Email :anita@wiraraja.ac.id
}

\begin{abstract}
Abstrak
Data limbah di Indonesia setiap tahun prosentasenya mengalami peningkatan. Pada tahun 2018, data limbah yang dihasilkan adalah $60 \%$ berasal dari sampah organik, $9 \%$ berasal dari sampah kertas, 4,3\% berasal dari sampah metal, 12,7\% berasal dari sampah kaca, kayu, dan bahan lainnya. Pada tahun 2019 Kementerian Lingkungan Hidup dan Kehutanan (KLHK) menyampaikan jumlah timbulan sampah secara nasional sebesar 175.000 ton per hari atau setara 64 juta ton per tahun, hal ini menggunakan asumsi sampah yang dihasilkan setiap orang perhari sebesar 0,7 Kg. Komposisi jenis sampah yang dihasilkan adalah 50\% berasal dari sampah organik (sisa makanan dan tumbuhan), 15\% berasal dari sampah plastik, $10 \%$ berasal dari sampah kertas, kemudian sisa sampah lainnya berasal dari logam, karet, kain, kaca dan lainnya.

Fakultas Teknik, Universitas Wiraraja wajib mempersiapkan lulusannya untuk siap bekerja, terlebih pada tahun 2015 negara-negara dikawasan Asia Tenggara menyepakati adanya Masyarakat Ekonomi Asean (MEA). Sumber daya manusia yang kreatif, inovatif, solutif dan dapat memanfaatkan sumber daya alam yang ada merupakan kekuatan utama dalam mewujudkan MEA. Sektor wirausaha diharapkan mampu berperan banyak dalam menghadapi MEA, karena wirausaha dapat merubah perekonomian suatu negara dengan sikap dan perilaku wirausaha itu sendiri untuk melakukan perubahan ke arah lebih baik. Berdasarkan pemaparan latar belakang diatas muncul ide kegiatan pengabdian kepada masyarakat dengan judul "Optimalisasi Daur Ulang Sampah Organik Dan Anorganik Untuk Meningkatkan Jiwa Enterpreneur Mahasiswa Teknik Sipil”. Hasil pelaksanaan berdasarkan penyebaran kuisioner kepada mitra menunjukan hasil yang cukup baik. Rata-rata jawaban responden yang menjawab "Ya" sebesar 94\% artinya responden memahami materi yang telah disampaikan dalam kegiatan sosialisasi.
\end{abstract}

Kata kunci : Optimalisasi sampah, Organik, Anorganik, Wirausaha

\section{Pendahuluan}

Indonesia adalah negara yang kaya sumber daya alam yang didukung oleh kondisi geografis, selain itu Indonesia mempunyai jumlah populasi dan penduduk yang banyak sehingga membutuhkan fasilitas umum. Salah satu cara untuk memajukan kesejahteraan Indonesia yaitu dengan pembangunan insfrastruktur.

Pembangunan insfrastruktur saat ini begitu pesat diantaranya pembangunanan perumahan, kantor, rumah sakit, dan jenis infrastruktur lainnya. Beton salah satu bahan bangunan yang pasti digunakan dan 
diterapkan oleh masyarakat sebab beton memiliki kuat tekan yang baik, dan tahan terhadap cuaca.

Beton adalah bahan bangunan komposit yang terbuat dari kombinasi agregat kasar, agregat halus dan semen. Beton sudah mengalami peningkatan dan perkembangan, saat ini beton sudah banyak digunakan diberbagai infrastruktur sebagai struktur utama, beton memiliki kuat tekan yang tinggi dan mampu menahan beban yang berat.

Bahan-bahan limbah di sekitar bisa dimanfaatkan sebagai bahan tambahan dalam campuran beton, hal tersebut dapat memberikan alternatif untuk memanfaatkan limbah - limbah yang tidak termanfaatkan, seperti botol kaca, dengan adanya pemanfaatan limbah botol kaca ini dapat mengurangi limbah botol kaca yang mencemari lingkungan.

Botol kaca adalah limbah yang dihasilkan dari kegiatan yang dihasilakan dari kegiatan industri dan rumah tangga yang tidak bisa terurai, apabila jumlahnya terlalu banyak maka akan merusak lingkungan, namun limbah kaca dapat dimanfaatkan kembali salah satunya sebagai bahan pengisi pada beton, karena kaca memiliki ketahanan terhadap cuaca.
Data limbah di Indonesia setiap tahun prosentasenya mengalami peningkatan. Pada tahun 2018, data limbah yang dihasilkan adalah $60 \%$ berasal dari sampah organik, $9 \%$ berasal dari sampah kertas, 4,3\% berasal dari sampah metal, $12,7 \%$ berasal dari sampah kaca, kayu, dan bahan lainnya (CNN Indonesia, 2018).

Pada tahun 2019 Kementerian Lingkungan Hidup dan Kehutanan (KLHK) menyampaikan jumlah timbulan sampah secara nasional sebesar 175.000 ton per hari atau setara 64 juta ton per tahun, hal ini menggunakan asumsi sampah yang dihasilkan setiap orang perhari sebesar 0,7 Kg. Komposisi jenis sampah yang dihasilkan adalah $50 \%$ berasal dari sampah organik (sisa makanan dan tumbuhan), $15 \%$ berasal dari sampah plastik, $10 \%$ berasal dari sampah kertas, kemudian sisa sampah lainnya berasal dari logam, karet, kain, kaca dan lainnya (Baqiroh, 2019).

Pada tahun 2020 Kementerian Lingkungan Hidup dan Kehutanan (KLHK) menyampaikan jumlah sampah nasional mencapai 67,8 juta ton. Pemerintah butuh melakukan kebijakan dan upaya-upaya luar biasa (extra ordinary effort) agar permasalahan 
sampah tidak terus meningkat. Jika hanya sebatas bussiness as usual, maka diperkirakan pada tahun 2050 komposisi sampah akan lebih dua kali lipat (Aditya, 2020).

Beberapa penelitian tentang penggunaan kembali sampah khususnya sampah kaca telah dilakukan diantaranya : Selvakumar, Geetha, Rangan, Sithrubi, \& Sathyashriya (In Press) dengan judul "Effect of glass powder as partial fine aggregate replacement on properties of basalt fibre reinforced concrete". Penelitian ini memanfaatkan limbah kaca dan serat basal sebagai agregat halus untuk memproduksi beton mutu tinggi. Hasil yang dicapai dari pengujian yang dilakukan di laboratorium menunjukkan penggantian $10 \%$ serbuk kaca meningkatkan kekuatan dan memiliki sifat ketahanan yang baik dibandingkan dengan konvensional beton. Kuat tekan 84,5 MPa, kuat lentur $11 \mathrm{MPa}$ dan kuat lentur belah dari 3,2 MPa tercapai.

Gerges, Issa, Fawaz, Jabbour, Jreige, \& Yacoub, (2018) dengan judul "Recycled Glass Concrete : Coarse and Fine Aggregates". Penelitian ini menggunakan Limbah kaca (botol hijau, coklat, dan transparan) sebagai agregat halus. Pasir grading, warna kaca, sumber limbah kaca (botol dan nonbotol), dan kekuatan campuran desain digunakan sebagai parameter. Selain itu limbah kaca botol hijau juga digunakan untuk agregat kasar. Parameter yang digunakan adalah limbah botol kaca yang lolos uji L.A. Abrasion. Hasil penelitian ini menunjukan bahwa Penggabungan pasir kaca terlepas dari rasio penggantian tidak menunjukkan pengaruh yang signifikan pada sifat segar atau mekanik beton kecuali untuk kasus botol transparan.

Selain latar belakang diatas, ada hal yang paling penting yang menjadi prioritas kegiatan pengabdian kepada masyarakat ini yaitu meningkatkan jiwa enterpreneur mahasiswa sebagai generasi penerus bangsa. Jika dilihat dari tujuan pendidikan yang dirumuskan dalam Undang-Undang Nomor 20 tahun 2003 tentang Sistem Pendidikan Nasional, Pasal 3, tujuan pendidikan nasional adalah mengembangkan potensi peserta didik agar menjadi manusia yang beriman dan bertakwa kepada Tuhan Yang Maha Esa, berakhlak mulia, sehat, berilmu, cakap, kreatif, mandiri, dan menjadi warga negara yang demokratis serta bertanggung jawab. Implikasinya, pendidikan harus berfungsi untuk 


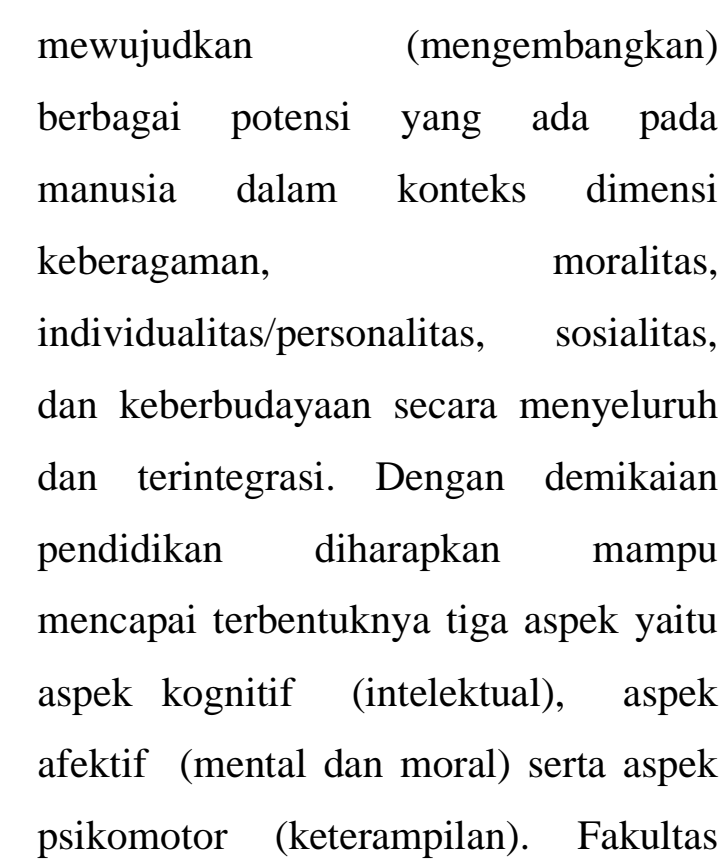

Teknik, Universitas Wiraraja wajib mempersiapkan lulusannya untuk siap bekerja, terlebih pada tahun 2015 negara-negara dikawasan Asia Tenggara menyepakati adanya Masyarakat Ekonomi Asean (MEA). Sumber daya manusia yang kreatif, inovatif, solutif dan dapat memanfaatkan sumber daya alam yang ada merupakan kekuatan utama dalam mewujudkan MEA. Sektor wirausaha diharapkan mampu berperan banyak dalam menghadapi MEA, karena wirausaha dapat merubah perekonomian suatu negara dengan sikap dan perilaku wirausaha itu sendiri untuk melakukan perubahan ke arah lebih baik.

Berdasarkan pemaparan latar belakang diatas muncul ide kegiatan pengabdian kepada masyarakat dengan judul “Optimalisasi Daur Ulang Sampah Organik Dan Anorganik Untuk Meningkatkan Jiwa Enterpreneur Mahasiswa Teknik Sipil”.

\section{Metode Pelaksanaan}

Adapun metode permasalahan yang akan dilaksanakan dalam kegiatan pengabdian kepada masyarakat dapat dilihat berdasarkan diagram alur berikut ini :

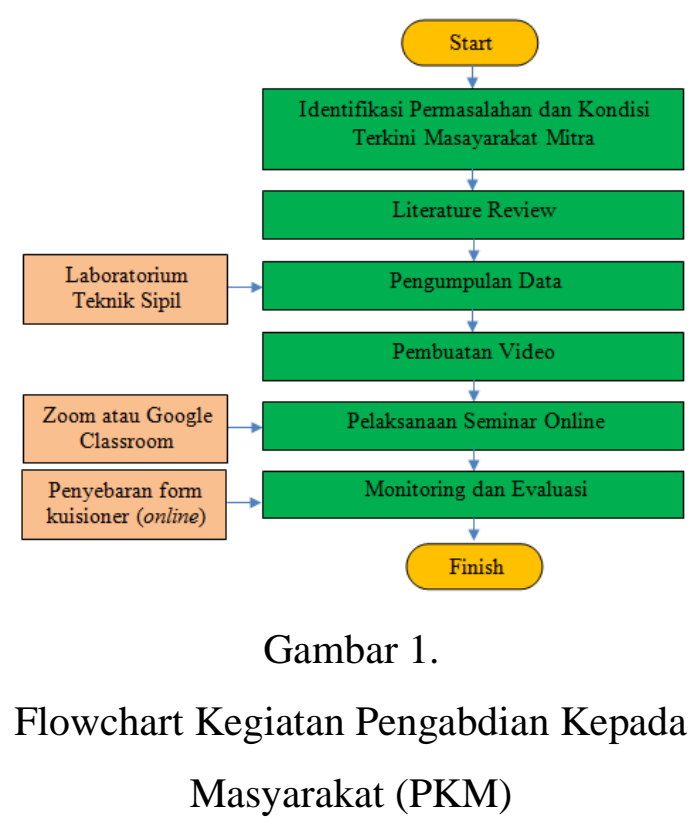

\section{Hasil dan Pembahasan}

Mitra dalam kegiatan pengabdian kepada masyarakat ini adalah himpunan mahasiswa Fakultas Teknik Universitas Wiraraja dimana mitra ini masuk dalam kategori mitra tidak produktif secara ekonomi/sosial. Himpunan mahasiswa 
Fakultas Teknik berlokasi di kampus Universitas Wiraraja.

Alasan pemilihan mitra tersebut sebagai partner dalam kegiatan pengabdian kepada masyarakat adalah banyak mitra yaitu mahasiswa yang mungkin sudah tahu keberadaan sampah baik sampah organik maupun sampah non organik, akan tetapi tidak mengetahui ada potensi apa di dalam sampah tersebut. Sehingga dirasa perlu oleh pihak pelaksana untuk mengadakan sosialisasi tentang optimalisasi daur ulang sampah organik dan non organik.

Kegiatan pengabdian kepada masyarakat ini dilaksanakan melalui aplikasi zoom meeting pada tanggal 16 Agustus 2021 pukul 10.00 s.d selesai. Pelaksanaan direncanakan melalui zoom meeting mengingat masih tingginya kasus virus corona di Kabupaten Sumenep. Kegiatan ini dihadiri oleh mahasiswa fakultas teknik baik program studi teknik sipil maupun teknik informatika. Karena keterbatasan jumlah participant yang disediakan oleh zoom maka kami batasi jumlah peserta kegiatan ini sebanyak 100 peserta. Kami menyediakan form pendaftaran melalui layanan google form dengan alamat https://forms.gle/qgiJJjUJCBt8gXxBA, sampai batas waktuyang telah ditentukan mahasiswa yang melakukan proses pendaftaran sebanyak 75 orang, akan tetapi real pada saat pelaksanaan mahasiswa yang hadir sebanyak 64 orang angka ini berdasarkan daftar hadir yang kami bagikan padaa saat acara di alamat

https://forms.gle/HGfUgiPL5P4Y3GmR

6. Materi yang disampaikan dalam acara sosialisasi adalah Materi 1 tentang terminologi umum, jenis sampah, permasalahan sampah, pengelolaan sampah, pemanfaatan sampah. Materi 2 tentang limbah serbuk kaca, limbah batok kelapa, dan kapur hidrolis sebagai material conblock. Materi 3 tentang limbah kaca dan abu daun bambu sebagai material conblock. Materi 4 tentang limbah plastik sebagai material paving block. Berikut ini merupakan dokumentasi selama kegiatan dilaksanakan,

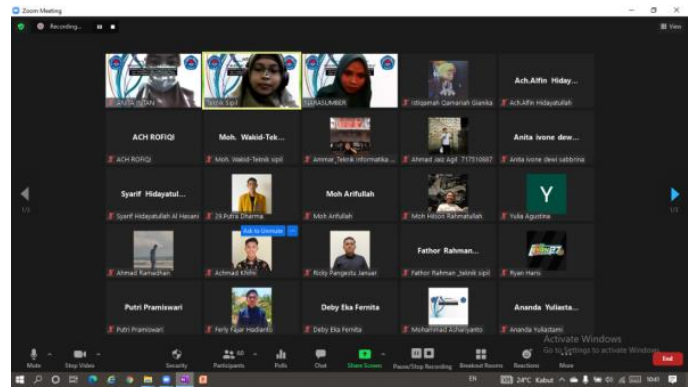

Gambar 2.

Pelaksanaan PKM melalui zoom meeting 


Setelah pelaksanaan kegiatan
pengabdian kepada masyarakat
dilaksanakan maka untuk mengetahui
dampak sosialisasi ini tim pelaksana
menyebarkan kuisioner. Adapun
beberapa pertanyaan yang diajukan
kepada para peserta adalah:
1. Apakah anda memahami tentang
konsep pengelolaan sampah?
2. Apakah anda memahami potensi
limbah yang dapat dimanfaatkan?
3. Apakah anda mendapat gambaran
pemanfaatan limbah yang ada
disekitar kita? anda mendapatkan
4. Apakah andangan
gambaran bagaimana cara membuat
paving block dari limbah?
5. Apakah anda mendapatkan
gambaran usaha yang dapat
memanfaatkan bahan limbah?

Kuisioner ini disebarkan melalui google form dengan alamat link https://forms.gle/9SA7iLvJ7mix YhUh7

Dari 64 peserta yang hadir, hanya 35 orang yang mengisi kuisioner ini. Penilaian terhada jawaban responden dilakukan dengan menggunakan jenis skala gutmenn, artinya jika responden menjawab "Ya" maka diberi skor 1, sedangkan jika responden menjawab "tidak" maka diberi skor 0. Jawaban secara rinci dapat dilihat pada tabel berikut ini,

Berdasarkan hasil jawaban responden maka dapat diketahui bahwa prosentase jawaban responden yang menjawab "ya" untuk pertanyaan no 1 adalah $97 \%$ dan prosentase jawaban responden yang menjawab "tidak" adalah $3 \%$. Prosentase jawaban responden yang menjawab "ya" untuk pertanyaan no 2 adalah $97 \%$ dan prosentase jawaban responden yang menjawab "tidak" adalah 3\%. Prosentase jawaban responden yang menjawab "ya" untuk pertanyaan no 3 adalah $83 \%$ dan prosentase jawaban responden yang menjawab "tidak" adalah 17\%. Prosentase jawaban responden yang menjawab "ya" untuk pertanyaan no 5 adalah $97 \%$ dan prosentase jawaban responden yang menjawab "tidak" adalah 3\%. Secara keseluruhan responden menjawab ya, artinya acara sosialisasi yang telah dilaksanakan banyak memberikan manfaat terutama tentang cara pengelolaan sampah menjadi produk yang memiliki nilai ekonomis seperti paving block. 
Kegiatan ini merupakan tahap paling awal dari peningkatan perekonomian mitra. Karena kegiatan sosialisasi tidak akan memberikan dampak yang signifikan jika tidak diikuti dengan tindak lanjut secara nyata untuk mewujudkan sebuah produk yang melibatkan mitra. Sehingga potensi keberlajutan dari program ini adalah sosialisasi cara pembuatan produk meliputi alat dan bahan yang dapat digunakan, setelah itu demplot pembuatan sampel produk yang dapat diwakili oleh beberapa orang yang menjadi bagian dari mitra itu sendiri.

Dengan adanya kegiatan lanjutan yaitu sosialisasi cara pembuatan produk, diharapkan mitra dapat mengetahui terlebih dahulu cara pembuatan produk, alat yang digunakan dan bahan yang dibutuhkan. Setelah sosialisasi ini dilakukan, maka dapat dilanjutkan dengan kegiatan berikutnya yaitu demplot pembuatan produk. Pada kegiatan ini, mitra akan secara langsung dapat mempraktekan bagaimana cara mengolah sampah menjadi sebuah produk yang bermanfaat dan memiliki nilai ekonomis.

Dua kegiatan diatas tidaklah cukup, mitra harus dibekali dengan cara menghitung biaya yang dibutuhkan untuk membuat sebuah produk dan cara memasarkan produk. Kegiatan ini dapat dikemas menjadi kegiatan workshop berdurasi pendek misalnya 2 hari. Hari pertama akan diagendakan bahwa mitra akan mendapatkan pelatihan bagaimana cara menghitung rencana anggaran biaya untuk sebuah produk, sehingga mereka dapat mengetahui berapa harga per m2 dari produk yang mereka hasilkan. Harga ini akan menjadi dasar dalam menentukan harga jual kepada konsumen. Kemudian hari ke-2 mitra akan dibekali bagaimana cara proses pemasaran produk yang baik, misalkan melalui sistem digital atau manual tatap muka.

\section{Kesimpulan}

Hasil pelaksanaan berdasarkan penyebaran kuisioner kepada mitra menunjukan hasil yang cukup baik. Rata-rata jawaban responden yang menjawab "Ya" sebesar 94\% artinya responden memahami materi yang telah disampaikan dalam kegiatan sosialisasi.

\section{Ucapan Terima Kasih}

Kami ucapkan terima kasih kepada pihak LPPM Universitas Wiraraja yang 
telah mendanai pelaksanaan kegiatan Pengabdian Kepada Masyarakat (PKM) dengan ditandai adanya surat kontrak $\begin{array}{lll}\text { No. } & 017 & \text { /SP2H/PKM- }\end{array}$ DI/LPPM/UNIJA/V/2021

\section{Daftar Pustaka}

Aditya, A. F. (2020). KLHK: Jumlah Sampah Nasional 2020 Mencapai 67,8 Juta Ton. Retrieved 2021, from https://www.idntimes.com/news/indo nesia/aldzah-fatimah-aditya/klhkjumlah-sampah-nasional-2020mencapai-678-juta-ton/3

Badan Standarisasi Nasional. (2000). SNI 03-2834-2000 tentang Tata cara pembuatan rencana campuran beton normal. Jakarta: Badan Standarisasi Nasional.

Baqiroh, N. F. (2019). Timbulan Sampah Nasional Capai 64 juta ton per Tahun. Retrieved 2021, from https://ekonomi.bisnis.com/read/2019 0221/99/891611/timbulan-sampahnasional-capai-64-juta-ton-per-tahun CNN Indonesia. (2018). Riset: 24 Persen Sampah di Indonesia Masih Tak Terkelola . Retrieved 2021, from https://www.cnnindonesia.com/gayahidup/20180425101643-282293362/riset-24-persen-sampah-diindonesia-masih-tak-terkelola
Gerges, N. N., Issa, C. A., Fawaz, S. A., Jabbour, J., Jreige, J., \& Yacoub, A. (2018). Recycled Glass Concrete : Coarse and Fine Aggregates. EJERS, European Journal of Engineering Research and Science Vol. 3, No. 1, $1-9$.

Selvakumar, M., Geetha, S., Rangan, S. K., Sithrubi, T., \& Sathyashriya, K. (In Press). Effect of glass powder as partial fine aggregate replacement on properties of basalt fibre reinforced concrete. Materials Today: Proceedings , 1-5.

Undang-Undang Nomor 20 Tahun 2003 tentang Sistem Pendidikan Nasional. 